\title{
Updated Review: Quality Parameters and Nutritional Values of Ostrich Meat
}

\author{
Muhammad Bilal Akram ${ }^{1 *}$, Syeda Azeema Hassan ${ }^{1}$, Shahiryar Khalid ${ }^{1}$, Muhammad Issa Khan ${ }^{2}$, Muhammad \\ Sheheryar ${ }^{3}$ \\ ${ }^{1}$ Student, National Institute of Food Science and Technology, Faculty of Food Nutrition and Home Science, University of \\ Agriculture, Faisalabad, Pakistan \\ ${ }^{2}$ Associate Professor, National Institute of Food Science and Technology, Faculty of Food Nutrition and Home Science, \\ University of Agriculture, Faisalabad, Pakistan \\ ${ }^{3}$ Student, School of Food Nutrition, Minhaj University, Lahore, Pakistan
}

*Address for Correspondence: Mr. Muhammad Bilal Akram, Student, National Institute of Food Science and Technology, Faculty of Food Nutrition and Home Science, University of Agriculture, Faisalabad, Pakistan

E-mail: mbilalakram3766@gmail.com

Received: 17 July 2018/ Revised: 16 Oct 2018/ Accepted: 18 Dec 2018

\begin{abstract}
The objective of this review article to collaborated on some important factors that affect ostrich meat quality. Few articles concluded that $\mathrm{pH}$ greatly influence ostrich meat quality. Protein content in ostrich meat is more as compared to any other red meat. At slaughtering, age has agreat effect on some ostrich meat quality such as lipid content and tenderness. Major issues likewise cardiovascular diseases, artheoseclorosis and other health threading problems can also be solved by consumption of ostrich meat because of low cholesterol level, low lipid content and less unsaturated fatty acid content as compared to any other red meat. Ostrich meat is also important for hypertension patient due to less sodium content.
\end{abstract}

Key-words: Artheoseclorosis, Cardiovascular disease, Meat quality, Nutritional value, Ostrich meat

\section{INTRODUCTION}

White meat production has increased last decade in the world due to consumer demand resulting in the decreased consumption of red meat. A major issue with consumption of red meat was increased cholesterol level, cardiovascular disease, artheoseclorosis and other such diseases that cause health problem. Therefore, white meat gains number one priority in the world ${ }^{[1]}$. Issues related to red meat might be solving by consumption of ostrich meat comparative to other red meat that recognizes as healthy. Ostrich is a flightless bird native to South Africa. In $19^{\text {th }}$ century ostrich feather was used as a fashion, for leather production and no one

\section{How to cite this article}

Akram MB, Hassan SA, Khalid S, Khan MI, Sheheryar M. Updated Review: Quality Parameters and Nutritional Values of Ostrich Meat. SSR Inst. Int. J. Life. Sci., 2019; 5(1): 2126-2129.

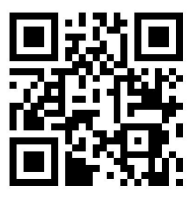

now real objective of ostrich meat and their products ${ }^{[2]}$. Now different countries produced ostrich meat and their farming is increasing. Recent decades, swift increased in population, urbanization, industrialization in Asia has developed meat industry to overcome to fulfill meat requirement. Therefore, an objective of this article to review some studies to check important factors that enhances ostrich carcass yield and meat quality.

Chemical composition and nutritional value- Meat is a flesh of animal that mainly composed of protein, fat, water and also contains other constituents ${ }^{[3]}$. Therefore, several types of researcher have conducted on chemical composition, quality composition and on the nutritional value of ostrich meat ${ }^{[4]}$. Meat of ostrich recognizes as healthy as compared to any other red meat that containing high percentage of poly unsaturated fatty acid, low cholesterol level ${ }^{[1]}$. Fat composition has a great effect on human health research indicates that ostrich meat has low intramuscular fat content (2.3\% average) [5]. Ostrich meat is a lean meat and having a low 
percentage of intramuscular lipid content, good for human health, due to low-fat content that affects juiciness of meat during mastication, an important factor that effect product in market ${ }^{[6]}$. Lipid content in ostrich meat varied from muscle to muscle. Lipid content is present in (M. flexor cruris) $1.44 \mathrm{~g} / 100 \mathrm{~g}, 0.88 \mathrm{~g} / 100 \mathrm{~g}$ present in (M. fibularis longus) ${ }^{[7]}$. Age play an important role on fatty acid profile, as age increased most monounsaturated fatty acid and saturated fatty acid was present in M. iliofibularis and polyunsaturated fatty acids M. gastrocnemius ${ }^{[8]}$. In ostrich meat, the most abundant fatty acid is Oleic acid (C18:1), palmitic acid (C16:0) and linoleic acid $(C 18: 2 n-6)^{[9]}$. Several types of researcher have been conducted on ostrich meat lipid content by using their different age content. It was concluded that there was no important difference between them but difference was present between them on quality basis. An older aged ostrich has more unsaturated fatty acid content ${ }^{[10]}$. Proximate composition of ostrich meat showed that ostrich meat contained higher protein content as compared to any other red meat ${ }^{[11]}$. Ostrich meat consists of the higher amount of protein content that is $28 \%$ as compared to other red meat. Creatine is the most abundant amino acid that is present in ostrich meat ${ }^{[12]}$. Research clearly indicates that ostrich meat contained high amount of ash content $1.81 \mathrm{~g} / 100 \mathrm{~g}$ and low level of sodium content $12.25 \mathrm{mg} / 100 \mathrm{~g}^{[13,14]}$

Physical Characteristics- The $\mathrm{pH}$ of ostrich meat is affected by many factors i.e. Bya stunning method, slaughtering method, packaging, and storage condition [15]. The $\mathrm{pH}$ is one of the basic parameter that is responsible for meat quality. The $\mathrm{pH}$ of ostrich meat follows between $<5.8$ and $>6.2^{[16]}$, that is further confirmed by Paleari et al. ${ }^{[17]}$. Literature indicates that $\mathrm{pH}$ range 5.8 to 6.2 was best for processing industry ${ }^{[18]}$. Meat quality is affected by the rate of $\mathrm{pH}$ change after slaughtering. Type of muscle is one of the important factors that affect post mortem $\mathrm{pH}$ decline ${ }^{[11]}$. The $\mathrm{pH}$ of ostrich meat high during slaughtering due to animal or bird gains stress condition that causes glycogen depletion. Therefore, such a protocol has not been developed by modern slaughter house, how to minimize this stress condition during slaughtering process. Quality of ostrich meat can also be checked by their tenderness because tenderness is also one of the basic parameter for acceptability by consumer because ostrich meat has low collagen to protein ratio. Ostrich meat also has lowfat content as compared to any other red meat ${ }^{[18]}$.

Tenderness of ostrich meat is more as compared to any other red meat because meat is tenderer that have more water in it. During cooking, low moisture loss, increased tenderness and juiciness but overcooking effect their tenderness ${ }^{[19]}$. Flavor and aroma are present in animals or birds in small concentration, flavor and aroma are different in different muscles but more flavor and aroma are developed during cooking process. These were chemical substances that existence in small quantity in fat and protein ${ }^{[20]}$. Color also most important factor that affect consumer acceptability or reject ability because color is one of the basic parameter that easily asses and detect by the consumer. Ostrich color varies from dark red to cherry red as compared to any other red meat ${ }^{[15]}$. There are other different factors likewise packaging condition, deboning and storage condition greatly affect the color of ostrich meat ${ }^{[21]}$. Meat has great ability to hold water for longer period of time during cutting, cooking and chewing because ostrich meat appearance, texture before and after cooking, juiciness due to its water holding capacity ${ }^{[22]}$. The $\mathrm{pH}$ and water holding capacity has influence relationship with each other [23] concluded that a change in $\mathrm{pH}$ cause variation in water holding capacity. It was investigated that increased in $\mathrm{pH}$ of ostrich meat that causes less decreased in water holding capacity of ostrich meat. Different packaging condition effect the shelf life of ostrich meat. Different packaging condition modified atmosphere packaging mixture; carbon dioxide mixture and carbon monoxide mixture were used. Carbon monoxide performs best result as compared to any other packaging condition, maintain color of meat and flavor ${ }^{[10]}$. Similarly Soriano et al. ${ }^{[24]}$ packed ostrich meat in high nitrogen, high vacuum, ambient air and higher oxygen atmosphere and concluded that microbial load was same in all packaging condition, color redness and lightness were more in oxygen packaging. A shelf life of red meat was 3 days less in oxygen packaging as compared to any other packaging condition.

\section{CONCLUSIONS}

Today, due to lack of information and knowledge there is a less demand for ostrich meat when ostrich meat and their product compared to any other red meat. Therefore, recently there demand and production is increasing. However, their production should be 
marketed as compared to any other red meat, their quality and nutritional value should be labeled on product and advertising the value of ostrich meat. In addition to, also enhance sensorial properties of ostrich meat that ostrich meat is more tender, juiciness, better flavor and texture as compared to any other red meat and there is necessity introduced ostrich meat healthy as compared to any other red meat because ostrich meat has less cholesterol, low fat percentage and high protein content.

\section{ACKNOWLEDGMENTS}

The authors are grateful to Associate Professor Dr. Muhammad Issa Khan for valuable comments to the manuscript.

\section{CONTRIBUTION OF AUTHORS}

All authors equally contributed in this review article.

\section{REFERENCES}

[1] Soriano A, Garcl A, Ruiz A, Gomez E, Pardo R, et al. Lipolysis, proteolysis, physicochemical and sensory characteristics of different types of Spanish ostrich salchichon. Meat Sci., 2007; 75(4): 661-68.

[2] Alexander RMN, Maloiy GMO, Njau R, Jayes AS. Mechanics of running of the ostrich (Struthio camelus). J. Zool., 2009; 187(2):169-78.

[3] Anderson EW, Shugans SM. Repositioning for changing preferences: the case of beef versus poultry. J. Consum. Res., 1991; 18(2): 219-32.

[4] Botha SST, Hoffman LC, Britz TJ. Physical meat quality characteristics of hot-deboned ostrich (Struthio camelus var. domesticus) Muscularis gastrocnemius, pars intern a during post-mortem aging. Meat Sci., 2007; 75(4): 709-18.

[5] Capita RT, Carlos AC. Effect of several packaging conditions on the microbiological, physicochemical and sensory properties of ostrich steaks during refrigerated storage. Food Microbiol., 2018; 72(1): 146-56.

[6] Cooper RG, Horbanczuk O. Anatomical and physiological characteristics of ostrich (Struthiocamellus var. domesticus) meat determinate its nutritional importance for man. Animal Sci. J, 2002; 73(3): 167-73.

[7] EnverBaris E, Bingoland O. Effect of packaging conditions on shelf-life of ostrich steaks. Meat Sci., 2008; 78(1-2): 143-52.
[8] Bengol EB, Ergun O. Effects of modified atmosphere packaging (MAP) on the microbiological quality and shelf life of ostrich meat. Meat Sci., 2011; 88(4): 774-85.

[9] Fernandez-Lopez J, Sayas-Barbera E, Munoz T, Sendra E, Navarro C, et al. Effect of packaging conditions on shelf-life of ostrich steaks. Meat Sci., 2008; 78(1): 143-52.

[10]Fisher P, Hoffman LC, Mellet FD. Processing and nutritional characteristics of value added ostrich products. Meat Sci., 2000; 55(2): 251-54.

[11]Girolami IG, Marsico A, D’Andrea F, Braghieri G, Napolitano, Cifuni G. Fatty acid profile, cholesterol content and tenderness of ostrich meat as influenced by age at slaughter and muscle type. Meat Sci., 2003; 64(3): 309-15.

[12]Hoffman LC, Muller $M$, Cloete SWP, Brand $M$. Physical and sensory meat quality of South African Black ostriches (Struthio camelus var. domesticus), Zimbabwean Blue ostriches (Struthio camelus australis) and their hybrid. Meat Sci., 2008; 79(2): 365-74.

[13]Lambooji CM, Potgieter CM, Britz GL, Nortje, Pieterse C. Effects of electrical and mechanical stunning methods on meat quality in ostriches. Meat Sci., 1999; 52(3): 331-37.

[14]Majewska D, Jakubowska M, Ligocki M, Tarasewicz Z, Szczerbin D, et al. Physicochemical characteristics, proximate analysis and mineral composition of ostrich meat as influenced by muscle. Food Chem., 2009; 117(2): 207-11.

[15]Naveena, BM, Mendirartta SK, Anjaneyulu ASK. 2004. Tenderization of buffalo meat using plant proteases from Cucumis trigonus roxb and Zingiber oficinale roscoe. Meat Sci, 2004; 68(3): 363-69.

[16]Otremba MM, Dikeman MA, Boylee AE. Refrigerated shelf life of vacuum packaged, previously frozen ostrich meat. Meat Sci., 52(3); 1999. 279-83.

[17]Paleari MA, Camisasca SA, Beretta G, Renon P, Corisco P, et al. Ostrich Meat: Physico-chemical characteristics and composition with turkey and bovine meat. Meat Sci., 1998; 48(3-4): 205-10.

[18]Botha SS, Hoffman LC, Britz TJ. Physical meat quality characteristics of hot-deboned ostrich (Struthio camelus var. domesticus) Muscularis gastrocnemius, pars intern a during post-mortem aging. Meat Sci., 2015; 75(4): 709-718. 
[19]Rosmini, MR, Perlo F, Pagan-Moreno JA, Gago-Gago MJ, Lopez-Sentovena MA. Thiobarbituric acid test by extractive method applied to pate. Meat Sci., 1996; 42(1): 103-110.

[20]Sales J. Histological, biophysical, physical and chemical characteristics of different ostrich muscle. J. Sci. Food Agr., 1995; 54(1): 329-36.

[21]Sales J, Hayes JP. Proximate, amino acid, mineral composition of ostrich meat. Food Chem., 1996; 56(2): 167-70.
[22]Sales J, Mellett FD. Post-mortem pH decline in different ostrich muscles. Meat Sci., 1995; 42(2): 235-38.

[23]Seydim. AC, Acton JC, Hall MA, Dawson PL. Effects of packaging atmospheres on shelf-life quality of ground ostrich meat. Meat Sci., 2006; 73(3): 503-10.

[24]Soriano A, Garci B, Gomez E. The roles of the proteasome and cathepsins $B, L, H$ and $D$, in ostrich meat tenderization. Meat Sci., 2007; 75(1): 661-68. 